\title{
Advanced Cu-free Bipolar Solid-state Lithium-ion Battery Promoted by Li+ Conductive Matrix Enabled Excellent Iron Oxide Anode
}

\section{Wujie Dong}

Shanghai Institute of Ceramics

Yantao Zhao

Peking University

Mingzhi Cai

Peking University

Chenlong Dong

Peking University

Wenqin Ma

Shanghai Institute of Ceramics

Jun Pan

Shandong University

Zhuoran Lv

Shanghai Institute of Ceramics

Hang Dong

Shanghai Institute of Ceramics

Yufeng Tang

Shanghai Institute of Ceramics

Fuqiang Huang ( $\nabla$ huangfq@mail.sic.ac.cn )

Shanghai Institute of Ceramics https://orcid.org/0000-0003-0526-5473

Article

Keywords:

Posted Date: March 3rd, 2022

DOI: https://doi.org/10.21203/rs.3.rs-1388188/v1

License: (1) (1) This work is licensed under a Creative Commons Attribution 4.0 International License.

Read Full License 


\section{Advanced Cu-free Bipolar Solid-state Lithium-ion Battery Promoted by $\mathrm{Li}^{+}$ Conductive Matrix Enabled Excellent Iron Oxide Anode}

Wujie Dong, ${ }^{1}$ Yantao Zhao, ${ }^{2}$ Mingzhi Cai, ${ }^{2}$ Chenlong Dong, ${ }^{2}$ Wenqin Ma, ${ }^{1}$ Jun Pan, ${ }^{1}$ Zhuoran Lv, ${ }^{1}$ Hang Dong, ${ }^{1}$ Yufeng Tang ${ }^{1 *}$, Fuqiang Huang ${ }^{1 *}$

${ }^{1}$ State Key Laboratory of High Performance Ceramics and Superfine Microstructure, Shanghai Institute of Ceramics, Chinese Academy of Sciences, Shanghai 200050, P. R. China

${ }^{2}$ State Key Laboratory of Rare Earth Materials Chemistry and Applications, College of Chemistry and Molecular Engineering, Peking University, Beijing 100871, P.R. China

\section{Abstract}

Bipolar lithium-ion batteries ( $b$-LIBs) with internal series configuration possess great advantages in conversion rate from theoretical energy density to practical values when compared with classic ones. Herein, advanced $\mathrm{Cu}$-free $b$-LIBs with further simplified structure can be achieved by utilizing an amorphous $\mathrm{Li}^{+}$conductive $\mathrm{Li}-\mathrm{Fe}-\mathrm{BO}_{2}$ matrix enabled iron oxide anode $\left(\mathrm{FeO}_{x}\right.$-LFBO) with intermediate cutoff voltage $(\geq 0.5 \mathrm{~V})$ beyond lithiation potential of $\mathrm{Al}$ foil. The rational designed LFBO matrix can serve as a $\mathrm{Li}^{+}$conductor/reservoir to enable fast $\mathrm{Li}^{+}$diffusion, a heterogeneous nano-reactor to interdict aggregation of $\mathrm{Fe}+\mathrm{Li}_{2} \mathrm{O}$ precipitates, a binder to aggregate particles, and a soft buffer to remit volume change. The $\mathrm{FeO}_{x}$-LFBO has a high tap density of $1.6 \mathrm{~g}$ $\mathrm{cm}^{-3}$, good electronic conductivity, and high $\mathrm{Li}^{+}$conductivity. As an anode the intermediate cutoff voltage of $0.5 \mathrm{~V}$, it harvests the admirable capacity of $710 \mathrm{~mA} \mathrm{~h} \mathrm{~g}^{-1}$ 
at $0.5 \mathrm{~A} \mathrm{~g}^{-1}$, excellent cycling stability (95\% after 1000 cycles), and capacitive rate capability (192 $\mathrm{mA} \mathrm{h} \mathrm{g}^{-1}$ at $\left.50 \mathrm{~A} \mathrm{~g}^{-1}\right)$. Such an excellent anode is assembled into a novel $\mathrm{Cu}$-free LIB, delivering an ultra-high energy density of $\sim 350 \mathrm{Wh} \mathrm{kg}^{-1}$, outstanding power density of $\sim 6700 \mathrm{~W} \mathrm{~kg}^{-1}$, and long-term cycling stability ( $75 \%$ after 2000 cycles), much better than state-of-the-art $\mathrm{Li}_{4} \mathrm{Ti}_{5} \mathrm{O}_{12}$ battery $\left(\leq 100 \mathrm{Wh} \mathrm{kg}^{-1}, \leq 5000 \mathrm{~W} \mathrm{~kg}^{-1}\right)$. Moreover, a Cu-free solid-state bipolar pouch cell is also fabricated sucessfully with high volatge of $7.6 \mathrm{~V}$, great cycling stability, and safety. This study may set off an upsurge in studying intermediate cut-off voltage anodes and novel $b$-LIBs in the future.

\section{Introduction}

Lithium-ion batteries (LIBs) have undergone countless improvements in cell configurations and electrode materials since been commercialized in 1991. Actually, the optimization of the cell configuration has played a crucial role for the higher energy density, higher power density, longer lifetime, better safety, and lower cost. ${ }^{1}$ For instance, despite of using identical $\mathrm{LiCoO}_{2}$ cathode and graphite anode, the engineers have successfully increased the energy density of such a LIB to $200 \mathrm{Wh} \mathrm{kg}^{-1}$ from an initial $80 \mathrm{Wh} \mathrm{kg}^{-1}$ through substantial optimizations in cell configurations. ${ }^{2}$ Bipolar lithium-ion batteries ( $b$-LIBs) possess an advanced stack configuration that ultimately simplifies the cell components and thus may arouse the next battery industry revolution.

As shown in Figure 1A, in $b$-LIBs, cathode and anode slurries are separately coated on both sides of the same current collector, whose each units (unit number $\mathrm{n} \geq 2$ ) are internal series connected other than external series of classic LIBs 
(Figure S1). Therefore, $b$-LIBs are more competitive in the application of electric vehicles while these electrified transportations need for the battery packs with working voltage of $300-500 \mathrm{~V} .{ }^{3}$ Detailed cell configurations and attempts have been performed in recent years. For example, the cathode and Li metal anode were coated on one side of internal series connected $\mathrm{Al}$ and $\mathrm{Cu}$ foils to fabricate a solid-state $b$-LIBs. ${ }^{4}$ To avoid the Li-alloying of $\mathrm{Al}$ foils at low potentials $(\sim 0.3 \mathrm{~V})$ and the oxidization of $\mathrm{Cu}$ foils at high potentials $(>3.5 \mathrm{~V})$, stainless steel was utilized as the current collector to achieve a workable $b$-LIBs. ${ }^{5}$ Regrettably, when compared with Al foil, stainless steel still has the disadvantages of high-voltage resistance, thickness, density, electronic conductivity, and cost. The Al foils designed for both cathode and anode are capable only if the anodes are replaced to high/intermediate cutoff voltage materials, such as $\mathrm{Li}_{4} \mathrm{Ti}_{5} \mathrm{O}_{12}{ }^{6-8}$ and $2,6-\mathrm{Naph}(\mathrm{COOLi})_{2}{ }^{9}$.

To the best of our knowledge, ideal $b$-LIBs (Figure 1A) should be designed by the following three points: (1) Traditional liquid electrolyte should be replaced to solid-state electrolyte to avoid short circuit between cathode and anode on the two sides of the same Al foil; (2) Single current collector should be applied to give full play to $b$-LIBs' advantages, while the most promising candidate is Al foil; (3) Anode materials with the intermediate cutoff voltage $(\geq 0.5 \mathrm{~V})$ and high capacity beyond $\mathrm{Li}_{4} \mathrm{Ti}_{5} \mathrm{O}_{12}$ should be well developed to satisfy point (2). Benefit from such design, three fascinating advantages of $b$-LIBs are: (1) a simple and compact design for higher energy density; (2) a high-voltage and current output 
for higher power density; (3) a short electron transfer for a homogeneous current distribution and lower ohmic resistance for greatly reduced heat production. ${ }^{1}$ Detailed comparison between LIBs and $b$-LIBs is shown in Figure 1B, where $b$ -

LIBs take advantages in almost all aspects except technology maturity.
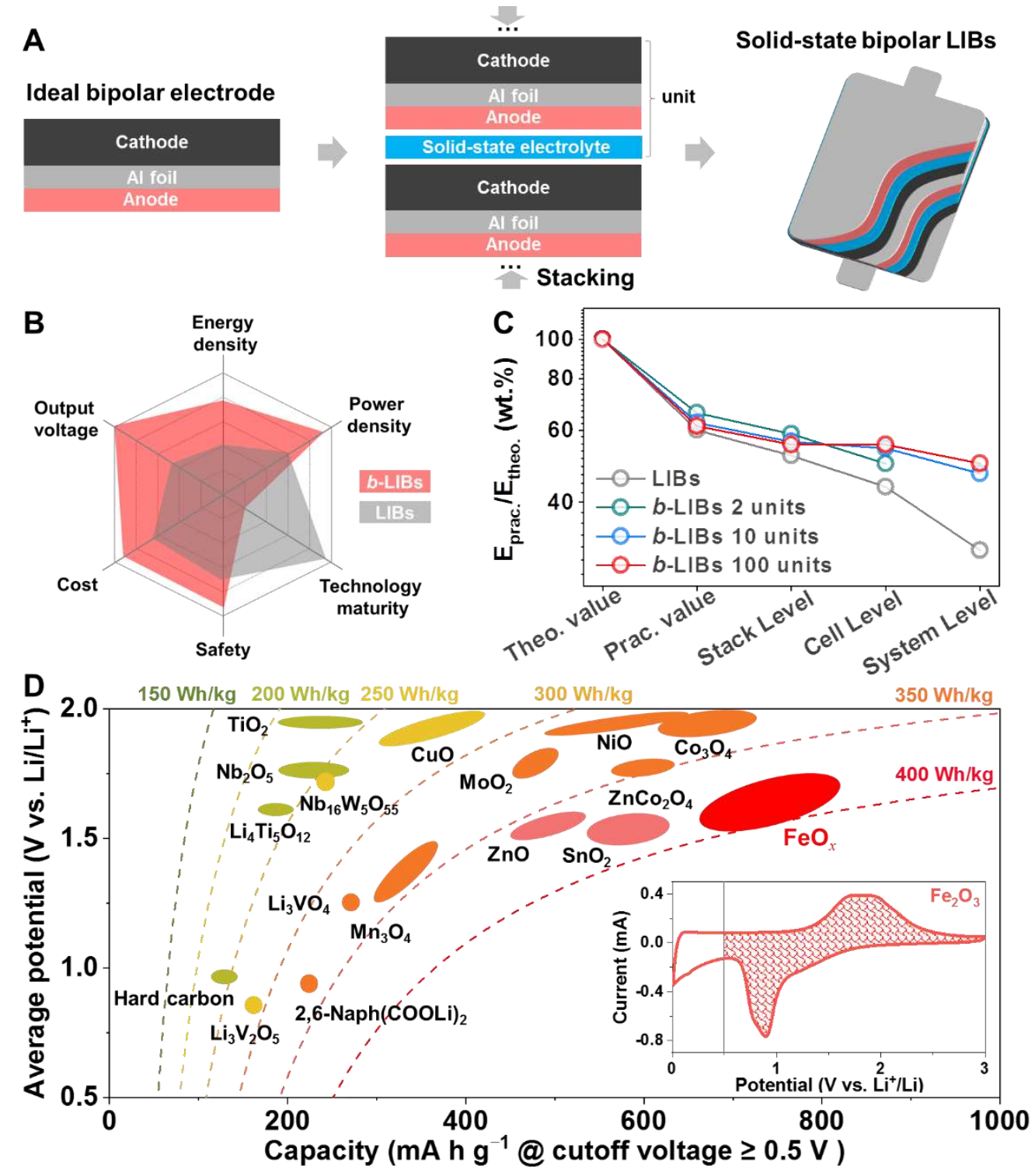

Figure 1. Comparison of classic LIBs and $\boldsymbol{b}$-LIBs. (A) Schematic images of ideal solid-state bipolar LIBs. (B) Spider diagram to show the properties of LIBs and $b$-LIBs. (C) Conversion rate from theoretical gravimetric energy density to practical values. (D) Average charge voltage of anode and energy density based on anode and cathode $\left(\mathrm{Wh} \mathrm{kg}^{-1}\right) v s$. anode capacity with the cutoff voltage $\geq 0.5$ $\mathrm{V}$. Cathode is assumed to be $4.6 \mathrm{~V} \mathrm{LiCoO}_{2}$ with specific capacity of $210 \mathrm{~mA} \mathrm{~h}$ $\mathrm{g}^{-1}$ with the average potential of $4.0 \mathrm{~V} v s$. $\mathrm{Li}^{2} / \mathrm{Li}^{+}$. Inset: Typical $\mathrm{CV}$ curves of $\mathrm{Fe}_{2} \mathrm{O}_{3}$ anode. 
Among these advantages, $b$-LIBs harvest inspiring enhancement when evaluating the practical energy density from theoretical values at cell or system level, as shown in Figure 1C and $\mathbf{S 2}$. The calculation steps and relevant data are referred from Betz's work. ${ }^{10}$ At cell level, the energy density conversion rate of state-of-the-art classic LIBs from theoretical to practical value is only 44 wt.\%/ 33 vol. $\%{ }^{10}$, while they can be improved up to $\sim 55$ wt.\%/ 41 vol. $\%$ in $b$ LIBs (100 units). When it comes to system level, the difference will be expanded further ( $\sim 30 \mathrm{wt} . \%$ for classic LIBs and $\sim 50 \mathrm{wt} . \%$ for $b$-LIBs) due to the additional components of power supply system for classic LIBs. The energy density at system level can be improved $67 \%$ from classic LIBs to $b$-LIBs cell configuration. Therefore, how to realize such ideal $b$-LIBs worth more efforts.

Ideal $b$-LIBs demand anodes with intermediate cutoff voltage $(\geq 0.5 \mathrm{~V})$ to prevent lithiation of $\mathrm{Al}$ foil $(\sim 0.3 \mathrm{~V})$, thus exclude the commercial graphite and $\mathrm{Si} / \mathrm{C}$ anodes, let alone the $\mathrm{Li}$ metal anodes. Metal oxide anodes with relatively high charge/discharge voltage are considered difficult to obtain an energy density higher than that of classic LIBs with graphite anode ${ }^{11,12}$. However, such a property is intrinsically suit for the $b$-LIBs. As shown in Figure 1D, the estimated anode capacity (cutoff voltage $\geq 0.5 \mathrm{~V}$ ), average charge potential, and estimated energy density of full cells for these metal oxide materials and relevant materials are summarized. Our newly developed $\mathrm{La}$ doped $\mathrm{LiCoO}_{2}{ }^{13}$ with high cutoff voltage of $4.6 \mathrm{~V}$ and high specific capacity of $210 \mathrm{~mA} \mathrm{~h} \mathrm{~g}^{-1}$ is assumed as the cathode. The speculated energy density of full cells with intercalation-type oxide 
anodes (e.g. $\mathrm{Li}_{4} \mathrm{Ti}_{5} \mathrm{O}_{12}, \mathrm{Nb}_{2} \mathrm{O}_{5}$, and $\mathrm{TiO}_{2}$ ) mainly ranges from 200 to $300 \mathrm{Wh} \mathrm{kg}^{-1}$, which can be enhanced to $300 \sim 350 \mathrm{Wh} \mathrm{kg}^{-1}$ by applying conversion-type oxide anodes (e.g. $\mathrm{Mn}_{3} \mathrm{O}_{4}, \mathrm{MoO}_{2}, \mathrm{NiO}$, and $\left.\mathrm{Co}_{3} \mathrm{O}_{4}\right)$. Iron oxide anodes, which have proper voltage and deliver most of the capacity under the voltage range of $0.5-$ 3.0 $\mathrm{V}$, can even make the energy density of full cell exceed $400 \mathrm{Wh} \mathrm{kg}^{-1}$, as exhibited in Figure 1D. Yet the critical issues of iron oxide anode on capacity fading and inefficient rate capability are still need to be overcome.

Herein, a rational designed amorphous $\mathrm{Li}^{+}$conductive $\mathrm{Li}-\mathrm{Fe}-\mathrm{BO}_{2}(\mathrm{LFBO})$ matrix is introduced to the iron oxides $\left(\mathrm{Fe}_{3} \mathrm{O}_{4}+\mathrm{Fe}_{2} \mathrm{O}_{3}\right.$ mixed phase $)$ anode $\left(\mathrm{FeO}_{x^{-}}\right.$ LFBO), which was sucessfully prepared by an newly developed electrostatic adsorption coprecipitation method. Such a LFBO matrix can serve as a $\mathrm{Li}^{+}$ conductor/reservoir to enable fast $\mathrm{Li}^{+}$diffusion, a heterogeneous nano-reactor to interdict aggregation of $\mathrm{Fe}+\mathrm{Li}_{2} \mathrm{O}$ precipitates, a binder to ameliorate contact between particles, and a soft buffer to remit volume change. The $\mathrm{FeO}_{x}$ - $\mathrm{LFBO}$ has a high tap density of $1.6 \mathrm{~g} \mathrm{~cm}^{-3}$ (much superior to graphite, $\mathrm{Si} / \mathrm{C}$, and $\mathrm{Li}_{4} \mathrm{Ti}_{5} \mathrm{O}_{12}$, $\sim 0.8-1.2 \mathrm{~g} \mathrm{~cm}^{-3}$ ), good electronic conductivity, and unexpected high $\mathrm{Li}^{+}$ conductivity. Under the voltage range of $0.01-3.0 \mathrm{~V}, \mathrm{FeO}_{x}$-LFBO harvests the admirable capacity of $933 \mathrm{~mA} \mathrm{~h} \mathrm{~g}^{-1}$ at $0.5 \mathrm{~A} \mathrm{~g}^{-1}$, excellent cycling stability (capacity retention $99 \%$ after 1000 cycles at $5 \mathrm{~A} \mathrm{~g}^{-1}$ ), and capacitive rate capability (683 $\mathrm{mA} \mathrm{h} \mathrm{g}^{-1}$ at $20 \mathrm{~A} \mathrm{~g}^{-1}$ and $384 \mathrm{~mA} \mathrm{~h} \mathrm{~g}^{-1}$ at $50 \mathrm{~A} \mathrm{~g}^{-1}$ ). With the intermediate cutoff voltage of $0.5 \mathrm{~V}, \mathrm{FeO}_{x}$-LFBO anode still maintains 709, 436, and $192 \mathrm{~mA} \mathrm{~h} \mathrm{~g}^{-1}$ at $0.5,20$, and $50 \mathrm{~A} \mathrm{~g}^{-1}$, respectively, much better than state- 
of-the-art anodes. For the first time, a novel $\mathrm{Cu}$-free LIB is assembled by our newly developed $\mathrm{La}-\mathrm{LCO}$ cathode and $\mathrm{FeO}_{x}$-LFBO anode, delivering a competitive energy density of $\sim 350 \mathrm{Wh} \mathrm{kg}^{-1}$ and outstanding power density of $\sim 6700 \mathrm{~W} \mathrm{~kg}{ }^{-1}$. Moreover, a prototype $\mathrm{Cu}$-free solid-state bipolar pouch full cell is also fabricated sucessfully with high volatge of $7.6 \mathrm{~V}$ and great cycling stability.

\section{Results}

Experimental demonstration. $\mathrm{FeO}_{x}$-LFBO was successfully prepared by a facile synthetic method, as schematic illustrated in Figure 2A. $\mathrm{Fe}(\mathrm{OH})_{3} \cdot \mathrm{Fe}^{3+}$ colloidal particles were obtained by a facile boiling water method, which can absorb $\mathrm{BO}_{2}^{-}$through electrostatic interaction and some $\mathrm{Li}^{+}$(from $\mathrm{LiBO}_{2}$ ) to form a $\mathrm{Li}-\mathrm{Fe}-\mathrm{BO}_{2}$ coated $\mathrm{Fe}(\mathrm{OH})_{3}$ co-precipitates. After aging 12 hours, these precipitates were separated, dried, and then annealed in $\mathrm{Ar}$ flow at $500{ }^{\circ} \mathrm{C}$ to obtain $\mathrm{FeO}_{x}$-LFBO. Referenced sample $\mathrm{FeO}_{x}$ was obtained by the same processing without adding $\mathrm{LiBO}_{2}$. The morphology of $\mathrm{FeO}_{x}$ with $\mathrm{Li}^{+}$conductive LFBO matrix was confirmed by transition electron microscopy (TEM), as shown in Figure 2B. $\mathrm{FeO}_{x}$-LFBO sample shows the big secondary particle, which is composed of $\mathrm{Fe}_{2} \mathrm{O}_{3}, \mathrm{Fe}_{3} \mathrm{O}_{4}$ (confirmed by Figure S3A), and the amorphous matrix. More clearly amorphous LFBO layer can be observed at the surface of $\mathrm{FeO}_{x}$ particles by high resolution TEM (HRTEM) with the thickness of $3.7-4.5$ nm, as shown in Figure 2C-D. The phase of these particles can be confirmed by measuring the interplanar spacing $\left(0.365 \mathrm{~nm}\right.$ for $\mathrm{Fe}_{2} \mathrm{O}_{3}(012)$ and $0.267 \mathrm{~nm}$ for $\left.\mathrm{Fe}_{2} \mathrm{O}_{3}(104)\right)$, angle between the crystal faces $\left(47^{\circ}\right.$ for $\mathrm{Fe}_{2} \mathrm{O}_{3}(012) /(104)$ and $27^{\circ}$ 
for $\left.\mathrm{Fe}_{2} \mathrm{O}_{3}(012) /(116)\right)$ and corresponding fast fourier transform (FFT) patterns, as shown in Figure 2D-E. For comparison, bare $\mathrm{FeO}_{x}$ sample is consisted of loosely packed particles with the size of $50-200 \mathrm{~nm}$, and the the suface is clean

(Figure S3B-C).

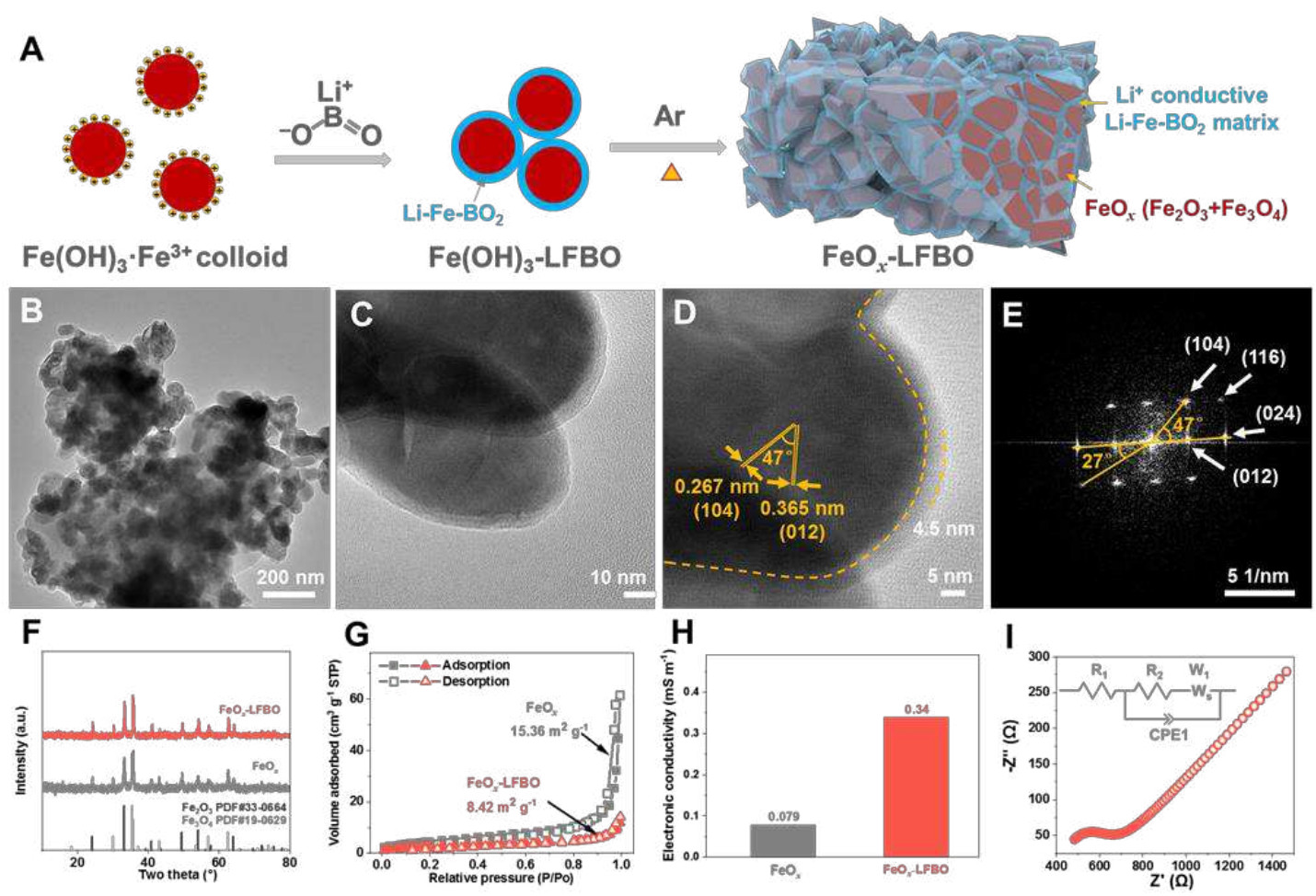

Figure 2. Schematic synthetic processing and basic characterization of FeO $x$-LFBO. (A) Schematic synthetic processing of $\mathrm{FeO}_{x}$-LFBO. (B) TEM images of $\mathrm{FeO}_{x}$-LFBO sample. Inset: Corresponding SAED patterns $\left(\mathrm{Fe}_{2} \mathrm{O}_{3}\right.$ and $\mathrm{Fe}_{3} \mathrm{O}_{4}$ ). (C-D) HRTEM images of $\mathrm{FeO}_{x}$-LFBO sample with amorphous Li-Fe$\mathrm{BO}_{2}$ coating layer. (E) Corresponding FFT patterns of (D). (F) XRD patterns, $(\mathrm{G})$ $\mathrm{N}_{2}$ adsorption-desorption isotherms, and $(\mathrm{H})$ electronic conductivity of the pressed pellets of $\mathrm{FeO}_{x}$ - $\mathrm{LFBO}$ and $\mathrm{FeO}_{x}$ samples. (I) Enlarged Nyquist plots spanning over $0.01-10^{5} \mathrm{~Hz}$ of $\mathrm{FeO}_{x}$-LFBO ceramic tablet. Inset: Randles equivalent circuit.

To further identify the components, X-ray diffraction (XRD) was utilized. The unannealed sample shows highly amorphous XRD patterns (Figure S4A) while annealed products contained two phase, $\mathrm{Fe}_{2} \mathrm{O}_{3}$ (JCPDS No. 33-0664) and $\mathrm{Fe}_{3} \mathrm{O}_{4}$ (JCPDS No. 19-0629), as shown in Figure 2F. To be noted, no signal of B 
species is observed in XRD patterns, indicating B species may be amorphous. Since Li and B are light elements, which cannot be detected by energy dispersive spectroscopy (EDS), thus we use inductively coupled plasma-atomic emission spectrometry (ICP-AES) to determinate the element ratio of $\mathrm{Li}: \mathrm{B}: \mathrm{Fe}$, which is $\sim 1: 2: 5.2$, indicating the composition of $\mathrm{FeO}_{x}$ - $\mathrm{LFBO}$ is $\mathrm{FeO}_{x} \cdot \mathrm{Li}_{0.2} \mathrm{Fe}_{0.1} \mathrm{~B}_{0.4} \mathrm{O}_{0.8}$. As shown in Figure S4B, and 2G, the specific surface area (SSA) of $\mathrm{Fe}(\mathrm{OH})_{3}$ precipitates and $\mathrm{Fe}(\mathrm{OH})_{3}-\mathrm{LFBO}$ precipitates are $289.56 \mathrm{~m}^{2} \mathrm{~g}^{-1}$ and $297.21 \mathrm{~m}^{2} \mathrm{~g}^{-1}$, respectively, which reduce to $15.36 \mathrm{~m}^{2} \mathrm{~g}^{-1}$ and $8.42 \mathrm{~m}^{2} \mathrm{~g}^{-1}$. Obviously, the SSA and the pore volume of $\mathrm{FeO}_{x}$ with LFBO matrix are much lower than the bare $\mathrm{FeO}_{x}$, which may benefit the initial coulombic efficiency, durability, and rate capability. Besides, the tap density of $\mathrm{FeO}_{x}$ - $\mathrm{LFBO}$ was also measured, which is as high as $\sim 1.6 \mathrm{~g} \mathrm{~cm}^{-3}$, much higher than that of carbon-contained anode materials.

We expect that $\mathrm{FeO}_{x}$-LFBO may have better electronic conductivity than bare $\mathrm{FeO}_{x}$ due to the adhesive effect of amorphous LFBO induced lower crystal interface resistance. To confirm, $I-V$ curves of pressed pellets $(\sim 0.5 \mathrm{~g}$ samples, $\Phi=13 \mathrm{~mm}$, thickness $\sim 1 \mathrm{~mm}$ ) of $\mathrm{FeO}_{x}$ and $\mathrm{FeO}_{x}$-LFBO were measured at room temperature. In Figure 2H, the apparent conductivity of $\mathrm{FeO}_{x}-\mathrm{LFBO}$ is higher than that of $\mathrm{FeO}_{x}$ by about 4.3 times, demonstrating that the interface resistance is the dominate issues. $\mathrm{FeO}_{x}$-LFBO was sintered to a ceramic tablet $(\sim 2 \mathrm{~mm} \times 4$ $\mathrm{mm}$ with the thickness of $\sim 0.7 \mathrm{~mm}$ ) by spark plasma sintering (SPS) at $500{ }^{\circ} \mathrm{C}$ with Ar protection. This tablet was then coated by silver paste on both side, dried, 
and clamped by stainless steel sheet. As shown in Figure 2I, the EIS test of such a tablet was performed spanning over $0.01 \mathrm{~Hz}$ to $10^{5} \mathrm{~Hz}$ ( $5 \mathrm{mV}$ excitation), also see the Randles equivalent circuit. The Nyquist plot shows a typical properties of solid-state electrolyte, with a half circle at high frequency and a tail at middleto-low frequency. The slop of the tail is quite low because of low ion diffusion efficiency of the sample. The calculation of ionic conductivity is based on $\sigma=$ $\mathrm{d} /(\mathrm{RS})=1.4 \mathrm{mS} \mathrm{cm}{ }^{-1}$, where $\mathrm{d}$ is the thickness $(\sim 0.7 \mathrm{~mm}), \mathrm{S}$ is the area $(\sim 2 \mathrm{~mm}$ $\times 4 \mathrm{~mm}), \mathrm{R}$ is total resistance (612 $\Omega$, fitted by Zview 2$)$. On the contrary, the bare $\mathrm{FeO}_{x}$ sample shows meaningless splashes because it is not an electrolyte for ions. We suspect the origin of this unexpected ionic conductivity is originated from the amorphous $\mathrm{Li}-\mathrm{Fe}-\mathrm{BO}_{2}$ matrix, and the $\mathrm{FeO}_{x}$ may work as the fillers with enhanced effect $^{14}$. Therefore, the amorphous LFBO matrix may work as a $\mathrm{Li}^{+}$ diffusion "expressway", a space-confined "nano-reactor", and a $\mathrm{Li}^{+}$"reservoir" to enable fast response of electrochemical reaction.

Electrochemical performance of $\mathrm{FeO}_{x}$-LFBO anode. Benefiting from this unique matrix, $\mathrm{FeO}_{x}$-LFBO electrode (counter electrode being a lithium foil) achieves excellent electrochemical performances. As shown in Figure S5, although achieving a high capacity at the begining, unmodified $\mathrm{FeO}_{x}$ anode exhibits the poor cycling durability, whose capacity fades to $100 \mathrm{~mA} \mathrm{~h} \mathrm{~g}^{-1}$ within only 50 cycles at galvanostatic charge-discharge (GCD) test of $0.1 \mathrm{~A} \mathrm{~g}^{-1}$. On the contrary, $\mathrm{FeO}_{x}$-LFBO anode delieves a little lower specific capacity of $\sim 870 \mathrm{~mA}$ $\mathrm{h} \mathrm{g}^{-1}\left(\sim 1400 \mathrm{~mA} \mathrm{~h} \mathrm{~cm}^{-3}\right)$ but harvests high initial coulombic efficiency of $\sim 75 \sim 80 \%$ 
and great durability at $0.1 \mathrm{~A} \mathrm{~g} \mathrm{~g}^{-1}$, which may be due to the extra component of “electrochemical inert” $\mathrm{Li}-\mathrm{Fe}-\mathrm{BO}_{2}$ matrix. The capacity of $\mathrm{FeO}_{x}-\mathrm{LFBO}$ increases during the following cycles with the top capacity over $1700 \mathrm{~mA} \mathrm{~h} \mathrm{~g}^{-1}(2720 \mathrm{~mA}$ $\mathrm{h} \mathrm{cm}^{-3}$, the mechanism of capacity increasing will be discussed later).
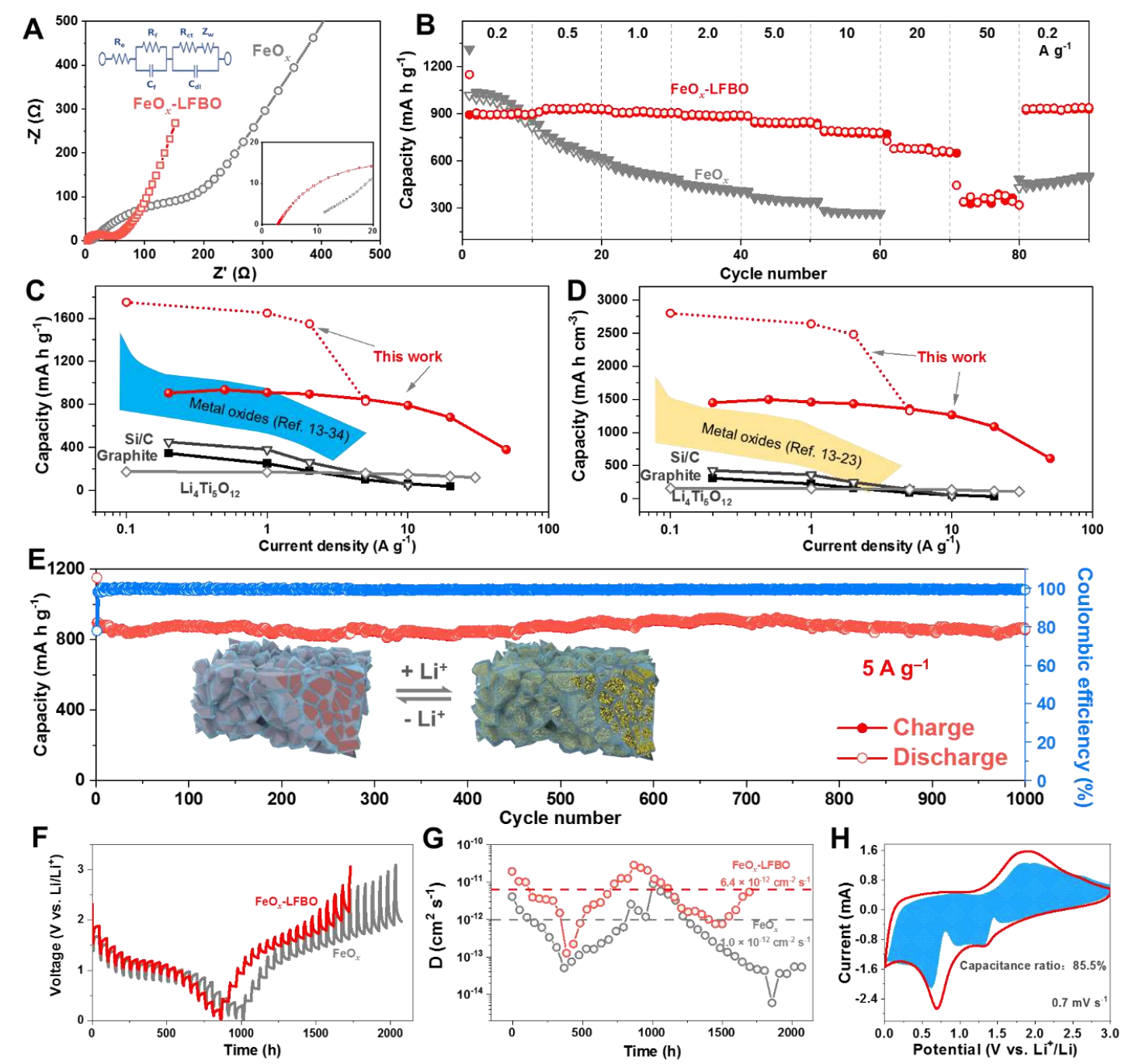

Figure 3. Electrochemical performance of $\mathrm{FeO}_{\boldsymbol{x}}$-LFBO anode. (A) Nyquist plots spanning over $0.01-10^{5} \mathrm{~Hz}$ of $\mathrm{FeO}_{x}$-LFBO and $\mathrm{FeO}_{x}$ electrodes. Inset: Randles equivalent circuit and enlarged Nyquist plots. (B) Rate capability of $\mathrm{FeO}_{x}$-LFBO and $\mathrm{FeO}_{x}$ electrodes. (C) Long-term cycling of $\mathrm{FeO}_{x}-\mathrm{LFBO}$ at $5 \mathrm{~A}$ $\mathrm{g}^{-1}$. Inset: Illustrated electrochemical reaction mechanism of $\mathrm{FeO}_{x}-\mathrm{LFBO}$ anodes. Comparison of the (D) specific gravimetric and (E) volumetric rate capability among the reported and commercial anode materials. (F) GITT profiles of $\mathrm{FeO}_{x^{-}}$ LFBO and $\mathrm{FeO}_{x}$ electrodes and $(\mathrm{G})$ the relevant $\mathrm{Li}^{+}$diffusion coefficient with different delithiation during charging or discharging. (H) The capacitance ratio fitting at $0.7 \mathrm{mV} \mathrm{s}^{-1}$. 
Initial five cyclic voltammetry (CV) curves of $\mathrm{FeO}_{x}$ - $\mathrm{LFBO}$ and $\mathrm{FeO}_{x}$ electrodes (Figure S5) were obtained at the scan rate of $0.3 \mathrm{mV} \mathrm{s}^{-1}$ over a voltage window of $3.0-0.01 \mathrm{~V}$. Specifically, for $\mathrm{FeO}_{x}$-LFBO (Figure S6A), the firstcycle reduction peak at $\sim 1.3 \mathrm{~V}$ is belonged to the formation of $\mathrm{Li}_{\mathrm{n}} \mathrm{FeO}_{x}{ }^{15}$, which shifts to $\sim 1.4 \mathrm{~V}$ afterwards due to the electrode activiation and remains stable. This peak is very weak in $\mathrm{FeO}_{x}$ (Figure S6B), which may because of its lower electronic and ionic conductivity. A strong and broad peak located at $\sim 0.6 \mathrm{~V}$ present the conversion reaction of $\mathrm{FeO}_{x}\left(\right.$ or $\left.\mathrm{Li}_{n} \mathrm{FeO}_{x}\right)$ and the formation of surface electrolyte interface (SEI) layer, which shift to $\sim 0.7 \mathrm{~V}$ after initial cycle. The peak near $0 \mathrm{~V}$ may result from the Li storage of $\mathrm{B}$ species, as indicated by our previous work ${ }^{16}$. The bare $\mathrm{FeO}_{x}$ have the similar but sharper peak located at $\sim 0.6$ $\mathrm{V}$ in the first-cycle, which shift to $\sim 0.9 \mathrm{~V}$ later. This difference may be due to the pre-lithiation reaction of $\mathrm{FeO}_{x}-\mathrm{LFBO}$ at $\sim 1.4 \mathrm{~V}\left(\mathrm{Li}_{\mathrm{n}} \mathrm{FeO}\right.$ ), while $\mathrm{FeO}_{x}$ does not. The broad oxidation peak located at $\sim 1.8 \mathrm{~V}$ is the oxidation reaction. The shape of CV curves are also related to the dynamic properties of the electrode, and the "fatter" curves of $\mathrm{FeO}_{x}$-LFBO imply the fast lithium storage.

Further electrochemical performance was inverstigated by EIS of $\mathrm{FeO}_{x^{-}}$ LFBO/Li half cell (0.01 Hz to $10^{5} \mathrm{~Hz}, 5 \mathrm{mV}$ excitation). As shown in Figure 3A, the equivalent series resistance $\left(\mathrm{R}_{\mathrm{e}}\right)$ and charge transfer resistance $\left(\mathrm{R}_{\mathrm{ct}}\right)$ of $\mathrm{FeO}_{x^{-}}$ LFBO electrode is $2.8 \Omega$ and $40 \Omega$, respectively, much small than those (11 $\Omega$ and $202 \Omega$ ) of the $\mathrm{FeO}_{x}$ electrode (fitted by Zview2). Smaller $\mathrm{R}_{\mathrm{e}}$ and $\mathrm{R}_{\mathrm{ct}}$ of $\mathrm{FeO}_{x^{-}}$ LFBO indicate the better electronic conductivity, which is consistent with result 
in Figure 2H. Furthermore, the slope of the tail at middle-low frequency present the Warburg resistance $\left(\mathrm{Z}_{\mathrm{w}}\right)$. Obviously, the slope of $\mathrm{FeO}_{x}$-LFBO electrode is bigger, indicating the faster $\mathrm{Li}^{+}$diffusion (capacitive-like $\mathrm{Li}^{+}$diffusion) than $\mathrm{FeO}_{x}$ electrode. The above in-direct evidences imply that $\mathrm{FeO}_{x}$-LFBO may serve better performance in fast charge/discharge.

Direct rate capability test spaning over $0.2 \mathrm{~A} \mathrm{~g}^{-1}$ to $50 \mathrm{~A}^{-1}$ was also performed with the active material loading mass of $\sim 1.0 \mathrm{mg} \mathrm{cm}^{-2}$, as shown in Figure 3B. The specific capacities are $\sim 906,936,911,896,848,791,680$, and $380 \mathrm{~mA} \mathrm{~h} \mathrm{~g}^{-1}$ $\left(\sim 1450,1498,1458,1434,1357,1266,1088\right.$, and $\left.608 \mathrm{~mA} \mathrm{~h} \mathrm{~cm}^{-3}\right)$ at $0.2,0.5,1$, $2,5,10,20$, and $50 \mathrm{~A} \mathrm{~g}^{-1}$, respectively. From initial current density of 0.2 to 20 $\mathrm{A}^{-1}$, the capacity retention is up to $75 \%$, much superior to the most reported results $^{15-36}$, as shown in Figure 3C-D. Long-term cycling of $\mathrm{FeO}_{x}-\mathrm{LFBO}$ at 1, 2, and $5 \mathrm{~A} \mathrm{~g} \mathrm{~g}^{-1}$ were also performed after initial 10 cycles at $0.1 \mathrm{~A} \mathrm{~g}^{-1}$. The initial capacities of all three cells are $\sim 870 \mathrm{~mA} \mathrm{~h} \mathrm{~g}^{-1}$, while the capacities increase gradully at 1 and $2 \mathrm{~A} \mathrm{~g}^{-1}$ until up to $\sim 1500 \mathrm{~mA} \mathrm{~h} \mathrm{~g}^{-1}$ after $400-500$ cycles (Figure S7), similar with it is at $0.1 \mathrm{~A} \mathrm{~g}^{-1}$ (Figure S5). At a large current density of $5 \mathrm{~A} \mathrm{~g} \mathrm{~g}^{-1}$, the capacity maintain stable with the retention of $98.9 \%$ even after 1000 cycles, reaching the demands of commercial application, as shown in Figure 3E. Besides, similar strategy of introduing $\mathrm{Li}^{+}$conductive matrix was also applied in developing $\mathrm{MnO}_{x}, \mathrm{CoO}_{x}$, and $\mathrm{SnO}_{2}$ based anode materials, whose electrochemical performance are also improved significantly, as shown in Figure 
S8. Other lithium salts such as $\mathrm{Li}_{2} \mathrm{SO}_{4}, \mathrm{Li}_{2} \mathrm{CO}_{3}$, and $\mathrm{LiCl}$, were also confirmed to show the similar performance improvement effect, as we reported before. ${ }^{37}$

In order to apply $\mathrm{Al}$ foil, the rate and cycling performance of $\mathrm{FeO}_{x}-\mathrm{LFBO}$ with the intermediate cutoff voltage of $0.5 \mathrm{~V}$ were also evaluated, as shown in Figure S9. The specific capacity $\mathrm{FeO}_{x}-\mathrm{LFBO}$ at $0.5 \mathrm{C}$ is $\sim 710 \mathrm{~mA} \mathrm{~h} \mathrm{~g}^{-1}$ under the voltage range of $3.0-0.5 \mathrm{~V}$ (safe cutoff voltage for $\mathrm{Al}$ foil), $\sim 76 \%$ of that in $3.0-0.01$ $\mathrm{V}$. Even at the high rate of 20 and $50 \mathrm{~A} \mathrm{~g}^{-1}$, it can also reach up to $\sim 440$ and $\sim 200$ mA h $\mathrm{g}^{-1}$ (Figure S10A). The cycling stability of $\mathrm{FeO}_{x}$-LFBO under the voltage range of $3.0-0.5 \mathrm{~V}$ is also excellent, maintaining over $95 \%$ capacity after 1000 cycles at $5 \mathrm{~A} \mathrm{~g}^{-1}$, as shown in Figure S10B.

Mechanism Analysis. Such an extremely stable cycling performance is originated from the novel structure of $\mathrm{FeO}_{x}$-LFBO, in which LFBO glass is a relatively soft and has better $\mathrm{Li}^{+}$conductivity than $\mathrm{Li}_{2} \mathrm{O}^{38-45}$. Therefore, this LFBO matrix can serve as $\mathrm{a} \mathrm{Li}^{+}$conductor/reservoir to enable fast response and diffusion of $\mathrm{Li}^{+}$, a heterogeneous nano-reactor to interdict aggregation of $\mathrm{Fe}+$ $\mathrm{Li}_{2} \mathrm{O}$ precipitates, a binder to ameliorate contact between particles, and a soft buffer to remit volume change, as illustrated in the inset of Figure 3E. Specifically, $\mathrm{FeO}_{x}$ little particles can gather to become big secondary particle with LFBO glass matrix, as illustrated in Figure $\mathbf{2 A}$ and confirmed by TEM image (Figure 2B-D). This LFBO glass matrix can reduce the interface electronic resistence and supply $\mathrm{Li}^{+}$at the first begining of electrochemical lithiation reaction $\left(\mathrm{Li}^{+}\right.$conductor/reservoir, Figure S11A-B). Thereafter, $\mathrm{Li}^{+}$in 
the electrolyte may replenish into LFBO matrix to balance the electric charge (Figure S11B-2). Thanks to such fine interface phase contact of $\mathrm{FeO}_{x}$ and $\mathrm{Li}^{+}$ source, the conversion reaction of $\mathrm{FeO}_{x}$ occurs more uniform (Figure S11C) and complete (Figure S11D) even at high rate. Moreover, as a heterogeneous layer, LFBO can interdict the movement and diffusion of $\mathrm{Li}_{2} \mathrm{O}$ and involved $\mathrm{Fe}$ from initial particles (Figure S11D-1, 2), thus prevent the agglomerates of small particles to a bigger one. And as a soft buffer, it can also act like the elastic 'plasticine' to remit the volume expansion and electrode cracking. For comparsion, without LFBO matrix, bare $\mathrm{FeO}_{x}$ electrode may suffer a fast particle coarsening and cracking (Figure S12), exhibiting quick capacity fading and bad rate capability (Figure 3B and S5). As shown in Figure S13, $\mathrm{FeO}_{x}$ nanoparticles are embedded in the LFBO materix without aggregation in cycled $\mathrm{FeO}_{x}$-LFBO electrode (500 cycles at $2 \mathrm{~A} \mathrm{~g}^{-1}$ ) while the particles are coarsed seriously in $\mathrm{FeO}_{x}$ electrode.

To reveal the origin of the superior rate capability of $\mathrm{FeO}_{x}$-LFBO, galvanostatic intermittent titration technique (GITT) was employed to study the electrode thermodynamics and kinetics process of $\mathrm{FeO}_{x}-\mathrm{LFBO}$ and $\mathrm{FeO}_{x}$ electrodes and the diffusion coefficients were calculated under various potentials, as shown in Figure 3F-G. The $\mathrm{Li}^{+}$diffusion coefficients were quantified according to the equation below.

$$
\mathrm{D}=\frac{4}{\pi \tau}\left(\frac{\mathrm{mV}_{\mathrm{m}}}{M S}\right)^{2}\left(\frac{\Delta \mathrm{E}_{\mathrm{s}}}{\Delta \mathrm{E}_{\mathrm{t}}}\right)^{2}
$$


where $\tau$ is the relaxation time $(2400 \mathrm{~s}), \mathrm{m}$ is the mass of iron oxides (based on $\left.\mathrm{Fe}_{2} \mathrm{O}_{3}\right), \mathrm{V}_{\mathrm{m}}$ is the molar volume, $\mathrm{M}$ is the molar mass, and $\mathrm{S}$ is the surface area of the electrode. $\Delta \mathrm{E}_{\mathrm{s}}$ and $\Delta \mathrm{E}_{\tau}$ are obtained from Figure 3E. Appearently, the diffusion coefficients of $\mathrm{FeO}_{x}-\mathrm{LFBO}$ are much higher than that of $\mathrm{FeO}_{x}$ during both the lithiation and delithiation reactions. the average the diffusion coefficient $\mathrm{D}_{\mathrm{Li}}$ of $\mathrm{FeO}_{x}-\mathrm{LFBO}$ is $\sim 6.4 \times 10^{-12} \mathrm{~cm}^{2} \mathrm{~s}^{-1}$, much superior to $\mathrm{FeO}_{x}$ and other metal oxide anodes. ${ }^{37,46}$

Further dynamic analysis was carried out by testing the CV curves at different scan rate over $0.3-0.7 \mathrm{mV} \mathrm{s}^{-1}$. As shown in Figure S14A-B, $\mathrm{FeO}_{x}$-LFBO and $\mathrm{FeO}_{x}$ electrodes exhibit different properties, where the reduction current peaks are located at $0.735 \mathrm{~V}$ and $0.696 \mathrm{~V}$ at 0.3 and $0.7 \mathrm{mV} \mathrm{s}^{-1}$, respectively. Thus the difference value is only $39 \mathrm{mV}$, much smaller than $84 \mathrm{mV}$ of the $\mathrm{FeO}_{x}$ electrode, which means $\mathrm{FeO}_{x}$-LFBO electrode has weaker voltage/ohmic polarization effect, leading to the better kinetic characteristics in electrode interface and lithium ion diffusion $^{47}$. It also indicates that the LFBO matrix can weaken the space potential layer, lower the surface potential, and restrain the side reaction to enhance the durability of the electrode. This result support the extraordinary rate capability (Figure 3B) and excellent long-term cycling performance (Figure 3E), and also consistent with the previous work $^{47}$. Furthermore, according the relationship between the current and the scan rate ${ }^{48,49}$ :

$$
I=a v^{b}
$$


where $I$ is the current, $v$ is the scan rate. Here we choose oxidation current peak at $\sim 1.8 \mathrm{~V}$ of $\mathrm{FeO}_{x}$-LFBO electrode because it is a single peak. As shown in Figure S14C, $-\log (i) v s .-\log (v)$ plot appears to be a liner relationship with the slope of ( $b$-value) of 0.88 . As suggested by Dunn $e t a l .{ }^{49}$, a $b$-value of 0.5 would indicate that the current is controlled by semi-infinite linear diffusion (battery), a value of 1 indicates that the current is surface-controlled (supercapacitor). Therefore, $\mathrm{FeO}_{x}$-LFBO electrode has a capacitive-like electrochemical Li storage property, which is further confirmed by capacitance ratio fitting by followed equation in Figure 3H:

$$
I=k_{1} v+k_{2} v^{1 / 2} \text { or } I / v=k_{1}+k_{2} v^{-1 / 2}
$$

As a result, the capacitance ratio in $\mathrm{FeO}_{x}$ - $\mathrm{LFBO}$ electrode can reach up to $85.5 \%$. This unexpected high value is resulted from the uniform interface lithiation/delithiation mechanism, which is induced by the $\mathrm{Li}^{+}$conductive LFBO matrix.

Aside from the dynamic properties, another interesting phenomenon of $\mathrm{FeO}_{x^{-}}$ LFBO electrode is the capacity increasing along with the cycling when the current density $<5 \mathrm{~A} \mathrm{~g}^{-1}$. To identify the origin of this increased capacity, GCD curves at $2 \mathrm{~A} \mathrm{~g}^{-1}$ are analyzed. As shown in Figure $\mathbf{S 1 5 A}$, the discharge capacity can be devided to two parts base on the voltage range of $3-0.7 \mathrm{~V}$ and $0.7-0.01$ $\mathrm{V}$. The capacity in $3-0.7 \mathrm{~V}$ is contributed by conversion reaction of $\mathrm{FeO}_{x}$, which is $\sim 650 \mathrm{~mA} \mathrm{~h} \mathrm{~g}^{-1}$ and remains stable along with the cycling. The capacity in 0.7 $\mathrm{V}-0.01 \mathrm{~V}$ can be attributed the lithium storage of B species, as indicated in our 
previous work ${ }^{16}$. This reaction is difficult to occur at first but may be activated during the long-term cycling and thus contribute increasing capacity. The relevent capacity contribution vs. cycle number in different votage ranges of 3.0 $-0.7 \mathrm{~V}$ and $0.7-0.01 \mathrm{~V}$ is shown in Figure S15B. Obviously, the capacity ratio in $3.0-0.7 \mathrm{~V}$ decrease from the initial $74.6 \%$ to $41.7 \%$ after 500 cycles, while the the capacity ratio in $0.7-0.01 \mathrm{~V}$ increase from the initial $25.4 \%$ to $58.3 \%$, demonstrating the gradual enhanced lithium storage properties of B species.

In order to confirm the above suspect, we performed the ex-situ B 1 s X-ray photoelectron spectroscopy (XPS) of cycled $\mathrm{FeO}_{x}$-LFBO electrodes. Normally, trivalent B $1 s$ is located at $\sim 192 \mathrm{eV}$, and it is deemed incapable of storaging $\mathrm{Li}^{16}$. However, as shown in Figure $\mathbf{S 1 5 C}$, after initial discharge to $0.01 \mathrm{~V}$, a weak peak located at $189 \mathrm{eV}$ can be also identified, which presents the extra-lithiated B. However, the ratio of this part is small, meaning that the most of B is inert and cannot storage Li, thus supply less capacity. After 500 cycles and discharge to $0.01 \mathrm{~V}$, the peak located at $189 \mathrm{eV}$ becomes major peak, consistent with the capacity increasing in Figure S15A. And after 500 cycles and charge to $3.0 \mathrm{~V}$, the B $1 s$ peak returns to higher binding energy, indicating the the Li storage of B specie is highly reversible. It can be found that the capacity increasement become slower along with the improvement of the current density. It is because the $\mathrm{Li}^{+}$ storage of B species is dynamically difficult thus cannot the activated at high rates. 

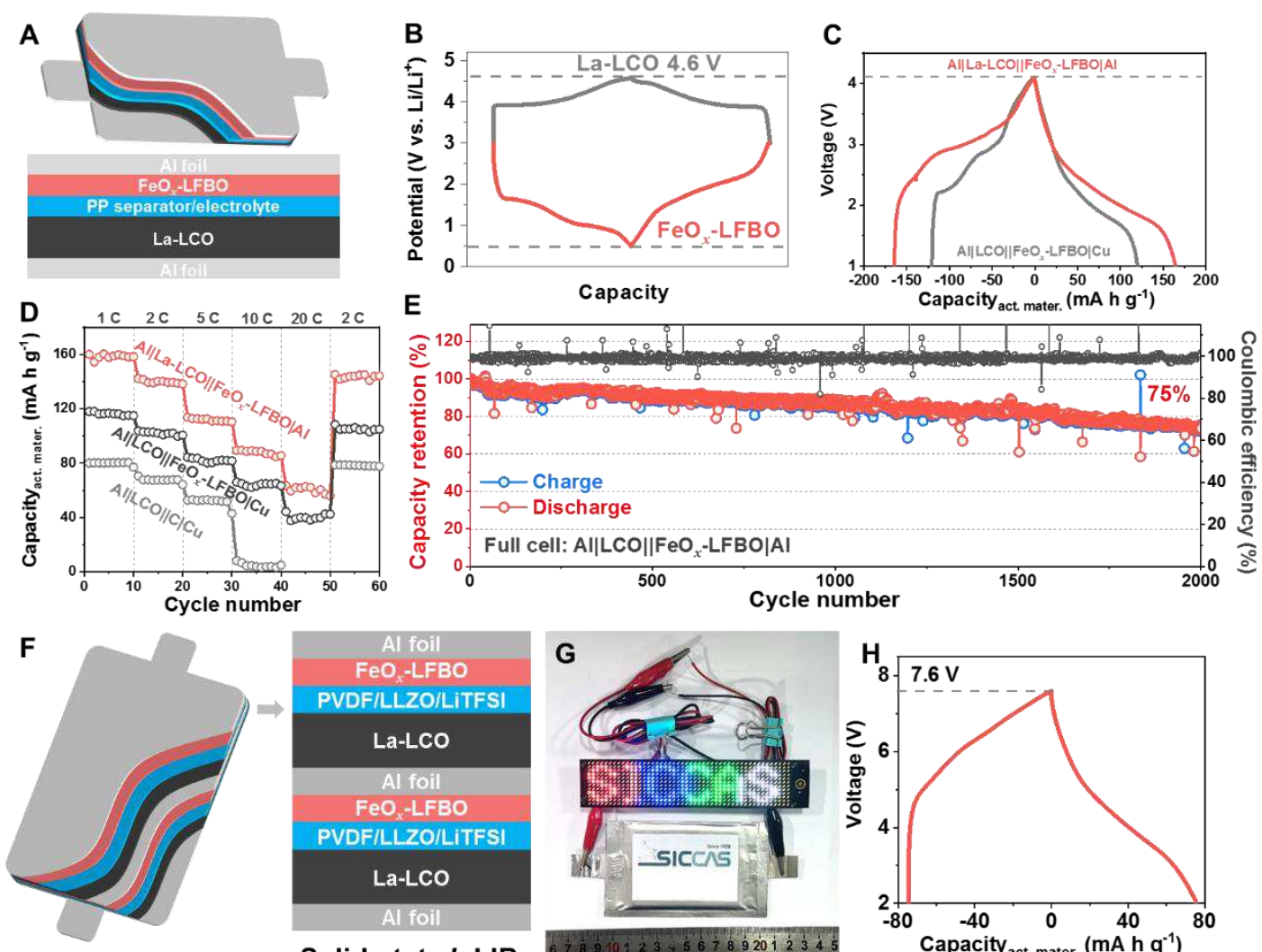

Solid-state $b$-LIB
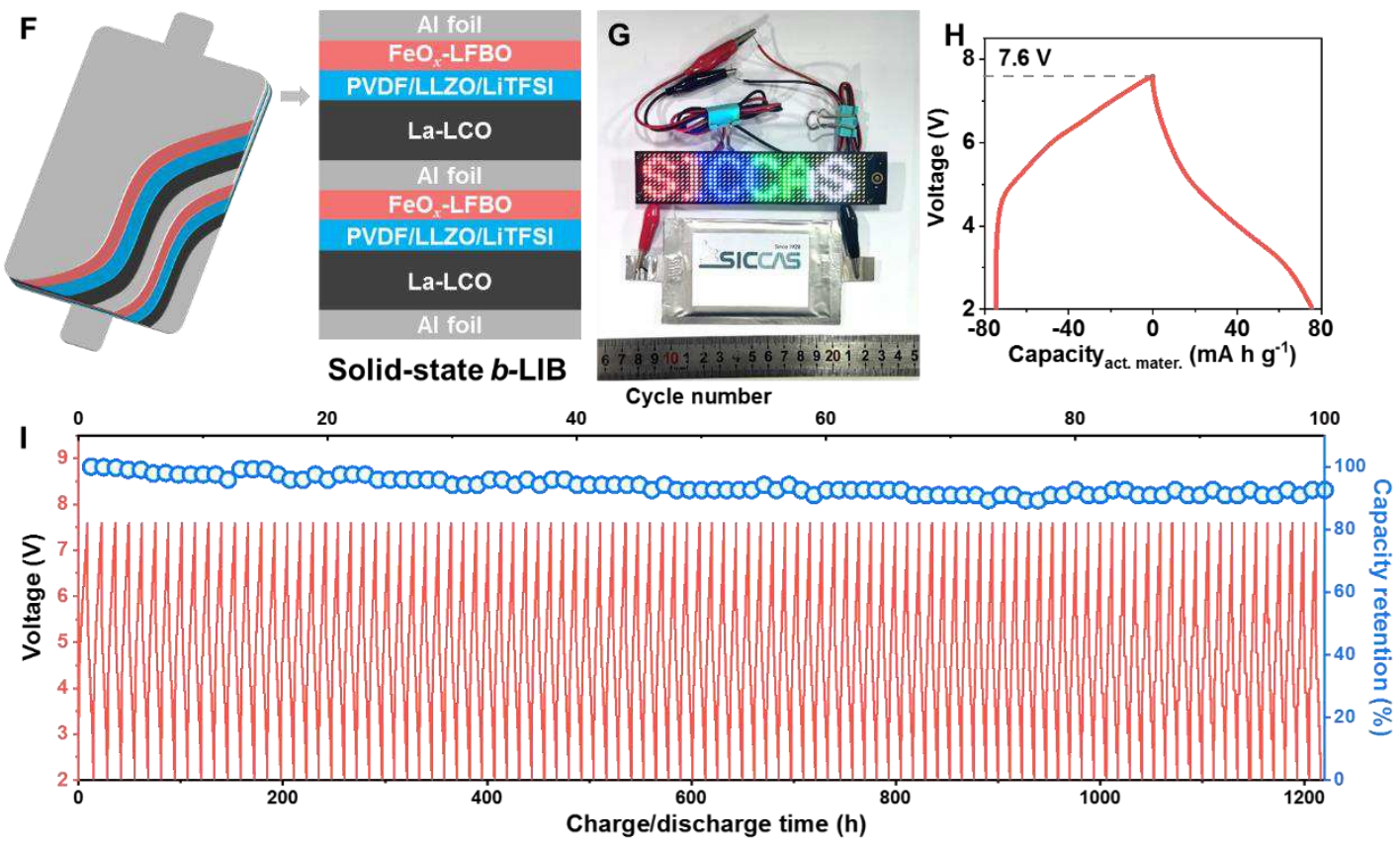

Figure 4. Fabrication and electrochemical performance of $\mathrm{Cu}$-free LIBs and $b$-LIBs full cells with $\mathrm{FeO}_{\boldsymbol{x}}$-LFBO anodes. (A) Schematic image of $\mathrm{Cu}$-free $\mathrm{Al} \mid \mathrm{La}-\mathrm{LCO} \| \mathrm{FeO}_{x}$-LFBO|Al full cell. (B) Illustrated GCD curves of our newly developed $\mathrm{La}-\mathrm{LCO}$ and $\mathrm{FeO}_{x}$-LFBO. (C) GCD curves of $\mathrm{Al} \mid \mathrm{La}-\mathrm{LCO} \| \mathrm{FeO}_{x^{-}}$ $\mathrm{LFBO} \mid \mathrm{Al}$ and $\mathrm{Al}\left|\mathrm{LCO} \| \mathrm{FeO}_{x}-\mathrm{LFBO}\right| \mathrm{Cu}$ full cells at $1 \mathrm{C}$. (D) Rate capabilities of $\mathrm{Al}\left|\mathrm{La}-\mathrm{LCO}\left\|\mathrm{FeO}_{x}-\mathrm{LFBO}|\mathrm{Al}, \quad \mathrm{Al}| \mathrm{LCO}\right\| \mathrm{FeO}_{x}-\mathrm{LFBO}\right| \mathrm{Cu}, \quad$ and traditional $\mathrm{Al}|\mathrm{LCO} \| \mathrm{C}| \mathrm{Cu}$ full cells ranging from $1-20 \mathrm{C}$. (E) Long-term cycling of Al|La$\mathrm{LCO} \| \mathrm{FeO}_{x}$-LFBO|Al full cell at $2 \mathrm{C}$. (F) Schematic image of $\mathrm{Cu}$-free solid-state $b$-LIB. (G) The digital image of pouch-type bipolar solid-state cell and a flexible LED light showing "SICCAS". (H) GCD curves Cu-free Al|La-LCO\|FeO ${ }^{-}$ LFBO|Al|La-LCO || $\mathrm{FeO}_{x}$-LFBO|Al bipolar solid-state cell. (I) Long-term cycling and relevant GCD curves of $\mathrm{Al}\left|\mathrm{La}-\mathrm{LCO}\left\|\mathrm{FeO} x^{-} \mathrm{LFBO}|\mathrm{Al}| \mathrm{La}-\mathrm{LCO}\right\| \mathrm{FeO}_{x^{-}}\right.$ LFBO|Al bipolar solid-state cell. 
Electrochemical performance of Cu-free LIBs. To evaluate the potential of $\mathrm{FeO}_{x}$-LFBO anode in practical application, electrodes with different loading mass spanning over $1.5-6.0 \mathrm{mg} \mathrm{cm}^{-2}$ are tested. As shown in Figure S16, capacities of various electrodes at low current density are similar, while the high rate capabilities exhibit great difference. Electrodes with the loading mass of 1.5 and $2.3 \mathrm{mg} \mathrm{cm}^{-2}$ show similare performance until the current density increase to $5 \mathrm{~A} \mathrm{~g}^{-1}$ (capacity of $\sim 680 \mathrm{~mA} \mathrm{~h} \mathrm{~g}^{-1}$ ), and remaining impressive capacities of $\sim 460$ and $320 \mathrm{~mA} \mathrm{~h} \mathrm{~g}^{-1}$ even at $20 \mathrm{~A} \mathrm{~g}^{-1}$, respectively. Electrode with the loading mass of $3.0 \mathrm{mg} \mathrm{cm}^{-2}$ also shows high capacity retention of $\sim 580 \mathrm{~mA} \mathrm{~h} \mathrm{~g}^{-1}$ at $5 \mathrm{~A}$ $\mathrm{g}^{-1}$ but reduces to only $\sim 220 \mathrm{~mA} \mathrm{~h} \mathrm{~g}^{-1}$ at $10 \mathrm{~A} \mathrm{~g}^{-1}$. Higher loading mass could make the high rate capacity lower.

We applied our newly developed La-doped $\mathrm{LiCoO}_{2}$ cathode ${ }^{13}$ (cutoff voltage 4.6 $\left.\mathrm{V}, \sim 210 \mathrm{~mA} \mathrm{~h} \mathrm{~g}^{-1}\right)$ and $\mathrm{FeO}_{x}$-LFBO anode $\left(3.0-0.5 \mathrm{~V}, 710 \mathrm{~mA} \mathrm{~h} \mathrm{~g}^{-1}\right)$ to fabricate $\mathrm{Cu}$-free sandwich structured full cells, as shown in Figure 4A-B. For comparison, cells with commercial $\mathrm{LiCoO}_{2}$ (cutoff voltage $4.2 \mathrm{~V}, \sim 140 \mathrm{~mA} \mathrm{~h} \mathrm{~g}^{-1}$ )

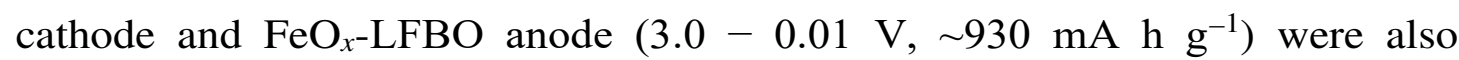
assembled (Figure S17 and 4C ). The loading masses of cathode materials are both $\sim 10 \mathrm{mg} \mathrm{cm}^{-2}$, while the matching loading masses of $\mathrm{FeO}_{x}$-LFBO anodes are $\sim 3.0$ and $1.6 \mathrm{mg} \mathrm{cm}^{-2}$, respectively $(\mathrm{N}: \mathrm{P}$ ratio $=1.01 \sim 1.05)$. The assembled full cells were both estimated under the voltage range of $4.1-1.0 \mathrm{~V}$. The GCD curves of $\mathrm{Al}|\mathrm{La}-\mathrm{LCO}|\left|\mathrm{FeO}_{x}-\mathrm{LFBO}\right| \mathrm{Al}$ and $\mathrm{Al}|\mathrm{LCO}|\left|\mathrm{FeO}_{x}-\mathrm{LFBO}\right| \mathrm{Cu}$ full cells are shown in Figure 4C, indicating that specific capacity of two cells are $\sim 160$ and $\sim 120$ 
$\mathrm{mA} \mathrm{h} \mathrm{g}^{-1}$ (basing on the total mass of cathode and anode active materials), respectively. The average discharge voltages of two cells are both $\sim 2.2 \mathrm{~V}$. The rate capabilities of $\mathrm{Al}\left|\mathrm{La}-\mathrm{LCO} \| \mathrm{FeO}_{x}-\mathrm{LFBO}\right| \mathrm{Al}$ and $\mathrm{Al}\left|\mathrm{LCO} \| \mathrm{FeO}{ }_{x}-\mathrm{LFBO}\right| \mathrm{Cu}$ full cells were evaluated, as shown in Figure 4D, which can harvest $\sim 60$ and $\sim 40 \mathrm{~mA}$ $\mathrm{h} \mathrm{g}^{-1}$ even at a ultrahigh rate of $20 \mathrm{C}$, much better than traditional $\mathrm{Al}|\mathrm{LCO} \| \mathrm{C}| \mathrm{Cu}$ cell. Therefore, $\mathrm{Al}|\mathrm{La}-\mathrm{LCO}|\left|\mathrm{FeO}_{x}-\mathrm{LFBO}\right| \mathrm{Al}$ can deliever a competitive energy density of $\sim 350 \mathrm{Wh} \mathrm{kg}^{-1}$ at $1 \mathrm{C}$ (theoretical energy density of $\sim 230 \mathrm{Wh} \mathrm{kg}^{-1}$ if using $\mathrm{Li}_{4} \mathrm{Ti}_{5} \mathrm{O}_{12}$ anode) and an outstanding power density reaching up to $\sim 6700$ $\mathrm{W} \mathrm{kg}^{-1}$ at $20 \mathrm{C}$. Besides, the cycling stability of $\mathrm{Al}\left|\mathrm{La}-\mathrm{LCO} \| \mathrm{FeO}_{x}-\mathrm{LFBO}\right| \mathrm{Al}$ was also performed at $80 \%$ DOD, which can remain $\sim 75 \%$ after long-term cycling of 2000 cycles, as shown in Figure 4E.

Electrochemical performance of $\mathrm{Cu}$-free solid-state b-LIBs. To evaluate the feasibility of $\mathrm{FeO}_{x}$-LFBO anode to apply to $b$-LIBs, a prototype $\mathrm{Cu}$-free Al|La$\mathrm{LCO} \| \mathrm{FeO}_{x}$-LFBO|Al|La-LCO $\| \mathrm{FeO}_{x}$-LFBO|Al bipolar solid-state pouch-type cell was fabricated, as shown in Figure 4F. Bipolar electrode is prepared by coating La-LCO cathode and $\mathrm{FeO}_{x}$-LFBO anode slurries on both sides of the same Al foil separately. High performance solid-state PVDF/LLZO/LiTFSI electrolyte $^{50}$ are applied with trace liquid electrolyte $(\sim 2$ wt.\%) to wet the electrode-electrolyte interface. The electrodes and solid-state films were stacked layer by layer and then rolled to enhance the interface contact, and finally cut to desired shape. The encapsulated pouch cell is exhibited in Figure 4G, which illuminates a flexible LED light. The relevant GCD curves (Figure 4H) indicate 
that such a $\mathrm{Cu}$-free $\mathrm{Al}\left|\mathrm{La}-\mathrm{LCO}\left\|\mathrm{FeO}_{x}-\mathrm{LFBO}|\mathrm{Al}| \mathrm{La}-\mathrm{LCO}\right\| \mathrm{FeO} x-\mathrm{LFBO}\right| \mathrm{Al}$ bipolar solid-state cell can deliver a high voltage of $7.6 \mathrm{~V}$ with the specific capacity of $\sim 70 \mathrm{~mA} \mathrm{~h} \mathrm{~g}^{-1}$ (based on the total active materials). Therefore, the energy density of such a $b$-LIBs can reach up to $\sim 310 \mathrm{Wh} \mathrm{kg}^{-1}$, which is roughly equivalent to $\mathrm{Cu}$-free LIBs. Moreover, the cycling stability of such a high voltage $b$-LIB is excellent, whose capacity retention can reach up to $92 \%$ after 100 cycles at 0.15 C, as shown in Figure 4I. Besides, to evaluate the safety of such a $\mathrm{Cu}$-free soildstate $b$-LIBs, pouch cells under bended, heated, and cut conditions were performed, which can still light the red LED bulbs without smoke and fire, as shown in Figure S18.

\section{Conclusions}

In summary, in order to satisfy the critical demands of $b$-LIBs, a rational designed amorphous $\mathrm{Li}^{+}$conductive LFBO matrix confined $\mathrm{FeO}_{x}$ anode was sucessfully prepared by a facile developed electrostatic adsorption coprecipitation method. This LFBO matrix can serve as a $\mathrm{Li}^{+}$conductor/reservoir to enable fast $\mathrm{Li}^{+}$diffusion, a heterogeneous nano-reactor to interdict aggregation of $\mathrm{Fe}+\mathrm{Li}_{2} \mathrm{O}$ precipitates, a binder to ameliorate contact between particles, and a soft buffer to remit volume change. This $\mathrm{FeO}_{x}$-LFBO have a high tap density, good electronic conductivity, and high $\mathrm{Li}^{+}$ conductivity. As the anode of LIB, it harvests the admirable capacity, excellent cycling stability, and capacitive rate capability. $\mathrm{Cu}$-free classic sandwich structured full cell with $\mathrm{FeO}_{x}$-LFBO anode is fabricated, delivering a competitive energy density of $\sim 350$ $\mathrm{Wh} \mathrm{kg}^{-1}$ at $1 \mathrm{C}$ and an outstanding power density reaching up to $\sim 6700 \mathrm{~W} \mathrm{~kg}^{-1}$ at $20 \mathrm{C}$. 
Moreover, a prototype bipolar solid-state cell is also assembled, which can achieve a high voltage of $7.6 \mathrm{~V}$ and good cycling stability. This study may set off an upsurge in the research of intermediate cut-off voltage anodes for the novel solid-state $b$-LIBs, such as oxides, sulfides, nitrides, and phosphorus based anodes.

\section{Methods}

All chemicals used in this work were analytical pure without any further purification and commercially available. Deionized water used was house generated. (Resistivity: $0.860 \mathrm{M} \Omega \cdot \mathrm{cm}$ at $25^{\circ} \mathrm{C}$, which is tested by Rex DDSJ308F Conductivity Meter).

Synthesis of $\mathrm{FeO}_{\mathbf{x}}$ and $\mathrm{FeO}_{\mathbf{x}}-\mathrm{LFBO}: \mathrm{FeO}_{x}$ were prepared by a simple hydrolysis precipitation method followed by an Ar atmosphere annealing processing. Briefly, $2.70 \mathrm{~g} \mathrm{FeCl}_{3} \cdot 6 \mathrm{H}_{2} \mathrm{O}(0.01 \mathrm{~mol})$ was solved in $10 \mathrm{~mL}$ DI water, which was then added into $200 \mathrm{~mL}$ boiling $\mathrm{DI}$ water under stirring to obtain $\mathrm{Fe}(\mathrm{OH})_{3} \cdot \mathrm{Fe}^{3+}$ colloidal solution. After aging 12 hours, these precipitates were separated, washed, freeze dried, and then annealed in Ar flow at $500{ }^{\circ} \mathrm{C}$ for 4 hours. $\mathrm{FeO}_{x^{-}}$ LFBO was prepared by the electrostatic adsorption coprecipitation method. Specifically, $\mathrm{LiBO}_{2}(2.50 \mathrm{~g}, 0.05 \mathrm{~mol})$ solutions $(45 \mathrm{~mL})$ was added into the above $\mathrm{Fe}(\mathrm{OH})_{3} \cdot \mathrm{Fe}^{3+}$ colloidal solution. The mixed solution was stirred for 12 hours before separation. The obtained product was freeze dried directly without washed, and the dried powder was annealed as above.

Synthesis of $\mathrm{CoO}_{\mathrm{x}}-\mathrm{LBO}, \mathrm{MnO}_{\mathrm{x}}-\mathrm{LBO}$, and $\mathrm{SnO}_{2}-\mathrm{LBO}$ : $\mathrm{CoO}_{x}-\mathrm{LBO}, \mathrm{MnO}_{x^{-}}$ LBO, and $\mathrm{SnO}_{2}-\mathrm{LBO}$ samples were obtained following a simple precipitation 
process. Specifically, $0.01 \mathrm{~mol}$ of cobalt (II) chloride, manganese (II) chloride, and tin (IV) chloride was first dissolved in $100 \mathrm{~mL}$ of DI water, and then $50 \mathrm{~mL}$ of $\mathrm{LiOH}$ solution $\left(0.6 \mathrm{~mol} \mathrm{~L}{ }^{-1}\right)$ was added to the solution under stirring. $\mathrm{LiBO}_{2}$ (2.50 g, $0.05 \mathrm{~mol})$ solutions (45 mL) was added into the above solution. After stirring for $12 \mathrm{~h}$, the precipitate was separated, freeze dried, and then annealed in Ar flow at $500{ }^{\circ} \mathrm{C}$ for 4 hours. $\mathrm{LiOH}$ was used as the precipitant since these metal ions cannot form colloidal particles by boiling water method.

Material characterization. Nitrogen adsorption-desorption isotherms at $77 \mathrm{~K}$ were measured by an Accelerated Surface Area \& Porosimetry system (ASAP2020, Micrometer) using vacuum-degassed samples $\left(120^{\circ} \mathrm{C}\right.$ for at least 4 h). These isotherms were used to calculate the specific surface area by the Brunauer-Emmett-Teller (BET) method. The chemical composition of the hybrid material was confirmed thru Inductively Coupled Plasma-Atomic Emission Spectrometer (ICP-AES, Prodigy 7 of Leeman Ltd.) to measure the atomic ratio of $\mathrm{Li}, \mathrm{Fe}$, and $\mathrm{B}$. The microstructures were characterized by transmission electron microscopy (TEM, JEM2010-HR). Powder X-ray diffraction (XRD) patterns were collected using a Bruker D2 X-ray diffractometer with $\mathrm{Cu} \mathrm{K} \alpha$ radiation $(k$ $=1.5418 \AA$ ) at a scanning rate of $2^{\circ} \mathrm{min}^{-1}$ in the $2 \theta$ range of $5^{\circ}-80^{\circ}$. X-ray photoelectron spectroscopy (XPS, Axis Ultra of Kratos Analytical Ltd. Al K $\alpha$ radiation, $h=1486.7 \mathrm{eV}$ ) was calibrated using the $284.8 \mathrm{eV}$ peak of delocalized $s p^{2}$-hybridized carbon that appeared on every sample due to atmospheric contamination. This procedure was repeated at the beginning of every XPS data 
analysis. Cycled samples were washed 3 times by dimethyl carbonate (DMC) to remove the residue electrolyte salts before XPS measurements.

Electrochemical measurements. An slurry consisting of 80 wt. $\%$ active material $\left(\mathrm{FeO}_{x}\right.$-LFBO and $\left.\mathrm{FeO}_{x}\right), 10$ wt $\%$ acetylene black, and 10 wt.\% polyvinylidene fluoride (PVDF/N-methyl pyrrolidinone) was uniformly coated to a $\mathrm{Cu} / \mathrm{Al}$ foil. Electrodes with different loading mass were obtained by using different thickness coater. The coated foil was dried at $100{ }^{\circ} \mathrm{C}$ for 12 hours in oven, then cut into disk electrodes of $12 \mathrm{~mm}$ in diameter. After that, the electrodes were further vacuum-dried overnight at $60{ }^{\circ} \mathrm{C}$. Lithium foil (China Energy Lithium Co., Ltd.) was used as the counter and reference electrode, and Celgard separator. The electrolyte used was $1 \mathrm{~mol} \mathrm{~L}^{-1} \mathrm{LiPF}_{6}$ in a 1: 1: 1 volume mixture of ethylene carbonate (EC), dimethyl carbonate (DMC), and ethyl methyl carbonate (EMC). Classic full coin cell was assembled by commercial LCO cathode, graphite anode, Celgard separator, and $1 \mathrm{~mol} \mathrm{~L}^{-1} \mathrm{LiPF}_{6}$ electrolyte. The negative to positive capacity ratio (N/P ratio) is $\sim 1.10 \pm 0.01$. $\mathrm{Cu}$-free full cell with sandwich structure is fabricated by using our newly developed La-LCO cathode ${ }^{13}, \mathrm{FeO}_{x}$-LFBO anode, and same separator/electrolyte. The N/P ratio is $1.05 \pm 0.01$. Cu-free bipolar full cell with 2 units is fabricated by using our newly developed La-LCO cathode, PVDF/LLZO/LiTFSI solid-state electrolyte ${ }^{50}$ with 2 wt.\% liquid electrolyte, and $\mathrm{FeO}_{x}-\mathrm{LFBO}$ anode. The N/P ratio is $1.01 \pm 0.01$. The loading masses of cathode for all full cells are $\sim 10 \mathrm{mg} \mathrm{cm}^{-2}$. All cells were assembled in a recirculating argon glovebox, which reserved the moisture and 
oxygen contents below $1 \mathrm{ppm}$. Electrochemical measurements were carried out on a LAND-CT2001C test system. The cycle lifetime of $\mathrm{FeO}_{x}$-LFBO half cells were characterized at different rates within a voltage window of $3.0-0.01 \mathrm{~V}$ or $3.0-0.5 \mathrm{~V}$. The rate capability was evaluated by varying the discharge-charge rate from 0.1 to $50 \mathrm{~A} \mathrm{~g}^{-1}$. Full cells with sandwich structure were evaluated at $4.1-1 \mathrm{~V}$. The rate capability was evaluated by varying the discharge-charge rate from 1 to 20 C. Pouch-type bipolar full cell was prepared and assembled in a dry room with a dew point below $-41{ }^{\circ} \mathrm{C}$. The assembled b-LIBs were first cycled for 2 cycles to complete the formation process before the long-term cycling at $7.6-2$ V. Electrochemical impedance spectroscopy (EIS), room-temperature I$V$ characteristics, and cyclic voltammetry $(\mathrm{CV})$ of the assembled coin cells were carried out using an automated electrochemical workstation (CHI660E and Autolab PGSTAT 302N from Switzerland). The EIS was measured between 0.01 $\mathrm{Hz}$ to $10^{5} \mathrm{~Hz}$ with an excitation voltage of $0.005 \mathrm{~V}$ at various potentials. The room-temperature $I$ - $V$ characteristics were accomplished in the votage range of $0.3 \mathrm{~V}$ to $+0.3 \mathrm{~V}$ at a scanning rate of $1 \mathrm{mV} \mathrm{s}^{-1}$. The $\mathrm{CV}$ curves were obtained at a scanning rate of $0.3 \mathrm{mV} \mathrm{s}^{-1}$ over the potential from 0.01 to $3.0 \mathrm{~V} v s . \mathrm{Li}^{+} / \mathrm{Li}$.

Theoretical energy density $\left(E_{0}\right)$ of the full cell with $\mathrm{FeO}_{x}$-LFBO anode is calculated by:

$$
\mathrm{E}_{0}=\oint \mathrm{VdC}=\oint \mathrm{V}_{\text {cathode }} \mathrm{dC}_{\text {cathode }}-\oint \mathrm{V}_{\text {anode }} \mathrm{dC}_{\text {anode }}
$$

where $\mathrm{V}$ is voltage range of the full cell, $\mathrm{C}$ is the capacity based on the total active material mass of cathode and anode. Specifically, $\mathrm{V}_{\text {cathode }}$ is $3.0-4.6 \mathrm{~V}$ for La- 
LCO with the loading mass of $10 \mathrm{mg} \mathrm{cm}^{-2}$ and the specific capacity of $210 \mathrm{~mA}$ $\mathrm{h} \mathrm{g}^{-1}$, and Vanode for $\mathrm{FeO}_{x}-\mathrm{LFBO}$ anode is $3.0-0.5 \mathrm{~V}$ with the loading mass of $3.0 \mathrm{mg} \mathrm{cm}^{-2}$ and the capacity of $710 \mathrm{~mA} \mathrm{~h} \mathrm{~g}^{-1}$. The practical energy density (E) of $\mathrm{Al}|\mathrm{La}-\mathrm{LCO}||\mathrm{FeOx}-\mathrm{LFBO}| \mathrm{Al}$ is calculated by:

$$
E=\oint V_{c e l l} d C
$$

where $\mathrm{V}_{\text {cell }}$ is the voltage range $1-4.1 \mathrm{~V}$ (average voltage is $\sim 2.2 \mathrm{~V}$ ) of full cell with the capacity of $160 \mathrm{~mA} \mathrm{~h} \mathrm{~g}$. Therefore, the calculated practical energy density is $\sim 350 \mathrm{Wh} \mathrm{kg}^{-1}$. And the power density $\mathrm{P}=\mathrm{E} / \mathrm{t}$, which is $\sim 6700 \mathrm{~W} \mathrm{~kg}^{-1}$ at $20 \mathrm{C}$.

\section{Data availability}

All data supporting the findings in the article as well as the Supplementary Information files are available from the corresponding authors on reasonable request.

\section{References}

1. Liu T, Yuan Y, Tao X, Lin Z, Lu J. Bipolar Electrodes for Next-Generation Rechargeable Batteries. Adv. Sci. 7, 2001207 (2020).

2. Li H. Practical Evaluation of Li-Ion Batteries. Joule 3, 911-914 (2019).

3. Vaidya R, Selvan V, Badami P, Knoop K, Kannan AM. Plug-In Hybrid Vehicle and Second-Life Applications of Lithium-Ion Batteries at Elevated Temperature. Batteries \& Supercaps 1, 75-82 (2018).

4. Shin HS, Ryu WG, Park MS, Jung KN, Kim H, Lee JW. Multilayered, Bipolar, All-Solid-State Battery Enabled by a Perovskite-Based Biphasic Solid Electrolyte. ChemSusChem 11, 3184-3190 (2018).

5. Wei ZY, et al. Superior lithium ion conduction of polymer electrolyte with comblike structure via solvent-free copolymerization for bipolar all-solid-state lithium battery. J. Mater. Chem. A 6, 13438-13447 (2018). 
6. Kim SH, Choi KH, Cho SJ, Yoo J, Lee SS, Lee SY. Flexible/shape-versatile, bipolar all-solid-state lithium-ion batteries prepared by multistage printing. Energy Environ. Sci. 11, 321-330 (2018).

7. Takami N, Yoshima K, Harada Y. 12 V-class bipolar lithium-ion batteries using $\mathrm{Li}_{4} \mathrm{Ti}_{5} \mathrm{O}_{12}$ anode for low-voltage system applications. J. Electrochem. Soc. 164, A6254 (2016).

8. Nam YJ, et al. Bendable and Thin Sulfide Solid Electrolyte Film: A New Electrolyte Opportunity for Free-Standing and Stackable High-Energy All-SolidState Lithium-Ion Batteries. Nano Letters 15, 3317-3323 (2015).

9. Ogihara N, Yasuda T, Kishida Y, Ohsuna T, Miyamoto K, Ohba N. Organic dicarboxylate negative electrode materials with remarkably small strain for highvoltage bipolar batteries. Angew. Chem. Int. Ed. 53, 11467-11472 (2014).

10. Betz J, Bieker G, Meister P, Placke T, Winter M, Schmuch R. Theoretical versus practical energy: a plea for more transparency in the energy calculation of different rechargeable battery systems. Adv. Energy Mater. 9, 1803170 (2019).

11. Zhang H, Wang L, Li H, He XM. Criterion for Identifying Anodes for Practically Accessible High-Energy-Density Lithium-Ion Batteries. ACS Energy Lett. 6, 3719-3724 (2021).

12. Dong C, Dong W, Lin X, Zhao Y, Li R, Huang F. Recent progress and perspectives of defective oxide anode materials for advanced lithium ion battery. EnergyChem 2, 100045 (2020).

13. Cai M, et al. Resolving oxygen crisis in high-voltage $\mathrm{LiCoO}_{2}$ by lanthurizing. Nat. Energy submited, (2022).

14. $\mathrm{Wu} \mathrm{N}$, et al. Enhanced Surface Interactions Enable Fast $\mathrm{Li}^{+}$Conduction in Oxide/Polymer Composite Electrolyte. Angew. Chem. Int. Ed. 132, 4160-4166 (2020).

15. Li L, et al. Enhanced Cycling Stability of Lithium-Ion Batteries Using GrapheneWrapped $\mathrm{Fe}_{3} \mathrm{O}_{4}-$ Graphene Nanoribbons as Anode Materials. Adv. Energy Mater. 5, $1500171(2015)$.

16. Dong W, et al. Boron Embedded in Metal Iron Matrix as a Novel Anode Material 
of Excellent Performance. Adv. Mater. 30, 1801409 (2018).

17. Lee JI, et al. High-performance silicon-based multicomponent battery anodes produced via synergistic coupling of multifunctional coating layers. Energy Environ. Sci. 8, 2075-2084 (2015).

18. Wu $\mathrm{H}$, et al. Stable Li-ion battery anodes by in-situ polymerization of conducting hydrogel to conformally coat silicon nanoparticles. Nat. Commun. 4, 1-6 (2013).

19. Huang $\mathrm{Y}$, et al. Revisiting the origin of cycling enhanced capacity of $\mathrm{Fe}_{3} \mathrm{O}_{4}$ based nanostructured electrode for lithium ion batteries. Nano Energy 41, 426-433 (2017).

20. Chen Y, Qian JF, Cao YL, Yang HX, Ai XP. Green Synthesis and Stable LiStorage Performance of FeSi2/Si@C Nanocomposite for Lithium-Ion Batteries. ACS Appl. Mater. Interface 4, 3753-3758 (2012).

21. Tian H, Tan X, Xin F, Wang C, Han W. Micro-sized nano-porous Si/C anodes for lithium ion batteries. Nano Energy 11, 490-499 (2015).

22. Huang YH, Bao Q, Duh JG, Chang CT. Top-down dispersion meets bottom-up synthesis: merging ultranano silicon and graphene nanosheets for superior hybrid anodes for lithium-ion batteries. J. Mater. Chem. A 4, 9986-9997 (2016).

23. Wang XP, et al. High-Density Monolith of N-Doped Holey Graphene for Ultrahigh Volumetric Capacity of Li-Ion Batteries. Adv. Energy Mater. 6, 1502100 (2016).

24. Wang Z, Luan D, Madhavi S, Hu Y, Lou XW. Assembling carbon-coated [small alpha]- $\mathrm{Fe}_{2} \mathrm{O}_{3}$ hollow nanohorns on the $\mathrm{CNT}$ backbone for superior lithium storage capability. Energy Environ. Sci. 5, 5252-5256 (2012).

25. Etacheri V, et al. Ordered Network of Interconnected $\mathrm{SnO}_{2}$ Nanoparticles for Excellent Lithium-Ion Storage. Adv. Energy Mater. 5, 1401289 (2015).

26. Gao GX, Wu HB, Lou XW. Citrate-Assisted Growth of $\mathrm{NiCo}_{2} \mathrm{O}_{4}$ Nanosheets on Reduced Graphene Oxide for Highly Reversible Lithium Storage. Adv. Energy Mater. 4, 1400422 (2014).

27. Cao Y, et al. A New Strategy to Effectively Suppress the Initial Capacity Fading of Iron Oxides by Reacting with $\mathrm{LiBH}_{4}$. Adv. Funct. Mater. 27, 1700342 (2017). 
28. Dong W, et al. A Robust and Conductive Black Tin Oxide Nanostructure Makes Efficient Lithium-Ion Batteries Possible. Adv. Mater. 29, 1700136 (2017).

29. Hu RZ, et al. Stabilizing the Nanostructure of $\mathrm{SnO}_{2}$ Anodes by Transition Metals: A Route to Achieve High Initial Coulombic Efficiency and Stable Capacities for Lithium Storage. Adv. Mater. 29, 1605006 (2017).

30. Bouchet R, et al. Single-ion BAB triblock copolymers as highly efficient electrolytes for lithium-metal batteries. Nat. Mater. 12, 452 (2013).

31. Liu N, et al. A pomegranate-inspired nanoscale design for large-volume-change lithium battery anodes. Nat. Nanotechnol. 9, 187-192 (2014).

32. Jeong S, Lee JP, Ko M, Kim G, Park S, Cho J. Etched Graphite with Internally Grown Si Nanowires from Pores as an Anode for High Density Li-Ion Batteries. Nano Letters 13, 3403-3407 (2013).

33. Xu Q, Li JY, Sun JK, Yin YX, Wan LJ, Guo YG. Watermelon-Inspired Si/C Microspheres with Hierarchical Buffer Structures for Densely Compacted Lithium-Ion Battery Anodes. Adv. Energy Mater. 7, 1601481 (2017).

34. Jiang T, Bu F, Feng X, Shakir I, Hao G, Xu Y. Porous Fe2O3 Nanoframeworks Encapsulated within Three-Dimensional Graphene as High-Performance Flexible Anode for Lithium-Ion Battery. ACS Nano 11, 5140-5147 (2017).

35. Kang E, et al. $\mathrm{Fe}_{3} \mathrm{O}_{4}$ Nanoparticles Confined in Mesocellular Carbon Foam for High Performance Anode Materials for Lithium-Ion Batteries. Adv. Funct. Mater. 21, 2430-2438 (2011).

36. Aravindan V, Lee YS. Electrochemical Activity of Hematite Phase in Full-Cell Li-ion Assemblies. Adv. Energy Mater. 8, 1702841 (2018).

37. Zhao Y, Dong W, Nong S, Lin X, Huang F. Assembling Iron Oxide Nanoparticles into Aggregates by $\mathrm{Li}_{3} \mathrm{PO}_{4}$ : A Universal Strategy Inspired by Frogspawn for Robust Li-Storage. ACS Nano, (2022). doi.org/10.1021/acsnano.1c10235

38. Smedley SI, Angell CA. Highly Conducting Li+-Rich Inorganic Glasses. Solid State Commun. 27, 21-23 (1978).

39. Button DP, Tandon RP, Tuller HL, Uhlmann DR. Fast Li+ Ion Conduction in Chloro-Borate Glasses. J. Non-Cryst. Solids 42, 297-306 (1980). 
40. Smedley SI, Angell CA. Fast Li+ Conduction in Fluoroborate Glasses. Mater Res. Bull. 15, 421-425 (1980).

41. Tuller HL, Button DP, Uhlmann DR. Fast Ion-Transport in Oxide Glasses. J. NonCryst. Solids 40, 93-118 (1980).

42. Martin SW. Ionic-Conduction in Phosphate-Glasses. J. Am. Ceram. Soc 74, $1767-$ $1784(1991)$.

43. Kodama M, Matsushita T, Kojima S. Velocity of Sound and Elastic Properties of $\mathrm{Li}_{2} \mathrm{O}-\mathrm{B}_{2} \mathrm{O}_{3}$ Glasses. Jpn. J. Appl. Phys. 1 34, 2570-2574 (1995).

44. Matsuda Y, Fukawa Y, Kawashima M, Mamiya S, Kodama M, Kojima S. Elastic properties and fragility of lithium borate glasses. Phys. Chem. Glasses-B 50, 367371 (2009).

45. Deng Z, Wang ZB, Chu IH, Luo J, Ong SP. Elastic Properties of Alkali Superionic Conductor Electrolytes from First Principles Calculations. J. Electrochem. Soc. 163, A67-A74 (2016).

46. Li R, Dong W, Pan J, Huang F. Micrometer-Sized, Dual-Conductive $\mathrm{MoO}_{2} / \beta$ $\mathrm{MoO}_{3-\mathrm{x}}$ Mosaics for High Volumetric Capacity Li/Na-Ion Batteries. Small Methods 5, 2100765 (2021).

47. Liang JY, et al. Mitigating Interfacial Potential Drop of Cathode-Solid Electrolyte via Ionic Conductor Layer To Enhance Interface Dynamics for Solid Batteries. J. Am. Chem. Soc. 140, 6767-6770 (2018).

48. Brezesinski T, Wang J, Polleux J, Dunn B, Tolbert SH. Templated NanocrystalBased Porous $\mathrm{TiO}_{2}$ Films for Next-Generation Electrochemical Capacitors. J. Am. Chem. Soc. 131, 1802-1809 (2009).

49. Augustyn $\mathrm{V}$, et al. High-rate electrochemical energy storage through $\mathrm{Li}+$ intercalation pseudocapacitance. Nat. Mater. 12, 518-522 (2013).

50. Pan J, et al. Quasi-Double-Layer Solid Electrolyte with Adjustable Interphases Enabling High-Voltage Solid-State Batteries. Adv. Mater., 2107183 (2021). 


\section{Acknowledgments}

This study was supported by the Science and Technology Commission of Shanghai Municipality (22ZR1471300) and the Key Research Program of

Frontier Science, Chinese Academy of Sciences (Grant No. QYZDJ-SSWJSC013 and KGZD-EW-T06).

\section{Author contributions}

F.H. and W.D. proposed the idea of this work and wrote the manuscript. W.D. and Y. Z. designed and conducted the experiments. M.C. prepared the cathode materials. C. D. performed the TEM test. J. P. and W. M. prepared the solid-state electrolyte. Z. L. and H. D. performed some material characterizations. Y. T. fabricated and evaluated full cells. All authors discussed the results and commented on the manuscript.

\section{Competing interests}

The authors declare no competing interests. 


\section{Supplementary Files}

This is a list of supplementary files associated with this preprint. Click to download.

- Sl.docx 